\title{
Review on Pumkin Production and Nutritional Value in Ethiopia
}

\author{
GETE FIKADU WOLDESENBET \\ Ethiopian Institute of Agricultural Research Holeta Agricultural Research Center Vegetable Research Program, \\ Ethiopia
}

\begin{abstract}
Among cucurbitaceous vegetables, pumpkin has been appreciated for high yields, long storage life and high nutritive value. All world continent produce pumpkin except Antarctica: including United States, Canada, Mexico, India, and China. Large number of pumpkin varieties varying in shape, size and colour of flesh are available. Cucurbita pepo, Cucurbita maxima and Cucurbita moschata are the worldwide commonly grown species of pumpkin. The weather of Ethiopia makes a suitable environment for the growth of pumpkin. Few years ago, farmers used to produce pumpkin in their gardens together with cereals, in farms near fences for the plants to easily creep on fences and houses, marginal or waste land, on decaying hay and heap of cow dung. It is commonly known to be used for both food and in herbal medicine formulation for the treatment of various ailments. Pumpkin contains biologically active compounds like polysaccharides, para-aminobenzoic acid, fixed oils, sterol, proteins and peptides. The fruits are a good source of carotenoid and $\gamma$ - aminobutyric acid. Pumpkin seeds are good sources of protein, fats, carbohydrates and minerals. It said to have contained $93 \%$ essential amino acids, $53 \%$ crude fat and $27 \%$ crude protein. The seed contains oil which is used for cooking. Pumpkin despite its enormous benefits, information on production, challenges and nutritive value was limited in Ethiopia. This is as a result of inadequate knowledge on its importance and how livelihoods of many families will be affected by its production. Therefore the objective of this paper was to review the production status and challenges and nutritive values of pumpkin in Ethiopia.
\end{abstract}

Keywords: pumpkin, nutritive value, production, Ethiopia

DOI: $10.7176 / \mathrm{JBAH} / 10-24-01$

Publication date: December $31^{\text {st }} 2020$

\section{INTRODUCTION}

Pumpkin belongs to the family Cucurbitaceae is a widely grown vegetable. It is the largest families in plant kingdom comprising of highest number of edible plant species. Pumpkin has species of Cucurbita moschata, Cucurbita pepo, Cucurbita maxima, Cucúrbita mixta, Cucurbita facifola and Telfairia occidentalis (Caili et al 2006). Cucurbita pepo, Cucurbita maxima and Cucurbita moschata are the worldwide commonly grown species of pumpkin. It is a small to medium sized vegetable plant generally grown for its fruits and edible seeds (Lee et al 2003).

The oldest evidence, pumpkin-related seeds dating between 7000 and $5500 \mathrm{BC}$, was found in Mexico. This plant is native of Northern Mexico and southwestern and eastern USA (Gohari et al., 2011). All world continent produce pumpkin except Antarctica: including United States, Canada, Mexico, India, and China. C. moschata is a most common variety of pumpk in Asia and United States of America. C. moschata is grown in almost all the regions of India while C. maxima mostly grown in the hills and subtropical regions. The main growing season is summer and rainy seasons but winter pumpkins are also grown in some parts of the world (Nath et al 1979).

Large number of pumpkin varieties varying in shape, size and colour of flesh are available. The miniature pumpkins are C. pepo (var. 'Jack OLantern') and the giant type (var. 'BostonMarrow' and 'Mammoth') tend to be C. maxima varieties. Buff coloured 'Sugar Pie' or 'Dickinson' and 'Kentucky' varieties; 'Buckskin' and 'Chelsey' hybrids of C. moschata are excellent fruits for processing.

The weather of Ethiopia makes a suitable environment for the growth of pumpkin. Few years ago, farmers used to produce pumpkin in their gardens together with cereals, in farms near fences for the plants to easily creep on fences and houses, marginal or waste land, on decaying hay and heap of cow dung. There are wide variations in fruit size, weight, shape, color, vine length and branching, leaf size, overall fruit subjective and chemical qualities and seed size among varieties (Meseret E, 2018).

It is commonly known to be used for both food and in herbal medicine formulation for the treatment of various ailments (Megersa et al., 2013). Pumpkin contains biologically active compounds like polysaccharides, paraaminobenzoic acid, fixed oils, sterol, proteins and peptides. The fruits are a good source of carotenoid and $\gamma$ aminobutyric acid (Bendich A, 1989). Due to its popular medicinal uses, researchers have focused over pumpkin from the last few decades, using modern tools, and credited pumpkin with antidiabetic, antihypertensive, antitumor, immunomodulative, antibacterial, anti-hypercholesterolemia, intestinal antiparasitial, anti-inflammatory and antalgic (Berteram JS, Bortkiewicz H, 1995).

Pumpkin seeds are good sources of protein, fats, carbohydrates and minerals (Bello et al., 2008). It said to have contained $93 \%$ essential amino acids, $53 \%$ crude fat and $27 \%$ crude protein [4]. The seed contains oil which 
is used for cooking (Okoli B E \& Nyanayo B, 1988). The oil has saponification value that is beyond the range for most oils of plants origin and less than that of palm oil. It also has high iodine value compared to palm oil, indicating that it has high content of unsaturated fatty acids relative to palm oil. Due to its high phosphorus content, it is said to be a potential agent in reducing kidney bladder stone disease (Suphakarn S, 1987). The anti-oxidative property of Fluted pumpkin seed oil could also enhance fertility (Murkovic M, 1996). Pumpkin despite its enormous benefits, information on production, challenges and nutritive value was limited in Ethiopia. This is as a result of inadequate knowledge on its importance and how livelihoods of many families will be affected by its production. Therefore the objective of this paper was to review the production status and challenges and nutritive values of pumpkin in Ethiopia.

\section{PUMPKIN HISTORY, TAXONOMY AND PRODUCTION}

\subsection{History of pumpkin}

Pumpkins are believed to have originated in North America. Seeds from related plants have been found in Mexico dating back to 7000 to 5500 B.C. The name pumpkin originated from the Greek word for "large melon" which is "pepon." "Pepon" was changed by the French into "pompon." The English changed "pompon" to "Pumpion." American colonists changed "pumpion" into "pumpkin" (Gohari et al., 2011).

\subsection{Taxonomy}

Pumpkin belongs to the family Cucurbitaceae and genus Cucurbita is a widely grown vegetable. Pumpkin has species of Cucurbita moschata, Cucurbita pepo, Cucurbita maxima, Cucúrbita mixta, Cucurbita facifola and Telfairia occidentalis. Three of these, Cucurbita pepo, Cucurbita maxima and Cucurbita moschata represent economically important species cultivated worldwide for human consumption (Caili et al 2006).

\subsection{Pumpkin production}

\subsubsection{Climate}

Pumpkin (Cucurbitaceae) are frost sensitive and need frost-free growing periods of 4 to 5 months. High temperatures (above $35^{\circ} \mathrm{C}$ ) and low humidity are not conducive to high yields. Temperatures of $20^{\circ} \mathrm{C}$ to $35^{\circ} \mathrm{C}$ are ideal for maximum production. Soil temperatures above $16^{\circ} \mathrm{C}$ are required for seeds to germinate and it can take up to 14 days for plants to emerge at this temperature. When the soil temperature rises to $20^{\circ} \mathrm{C}$, seeds emerge within a week, and at $25^{\circ} \mathrm{C}$, within four days of planting (Tony $\mathrm{N}, 2009$ ).(annual rain fall )wind effect

2.3.2. Soil and land preparation

Pumpkins can be grown on a wide range of soil types. As roots can penetrate up to a meter deep, a well-drained soil is preferred. Pumpkins grow best on well-drained fertile soils with $\mathrm{pH}$ water between 6.0 and 6.5 , although they will tolerate both slightly acid and slightly alkaline soils. Where soil $\mathrm{pH}$ is low (too acid), the application of lime or dolomite is necessary to allow better uptake of nutrients. For optimum results, incorporate the lime or dolomite into the soil at least six weeks before planting (Swiader et al., 1994). Add soil type

Good ground preparation is essential for high yields. Ripping is necessary if the soil has been compacted. The soil should then be ploughed 20 to $25 \mathrm{~cm}$ deep and worked to a fine tilth for planting. All organic matter should be incorporated into the soil well before planting to allow complete decomposition, otherwise there can be serious losses from damping-off diseases. Weed control is also important; with good preparation, many weeds can be controlled before sowing. Pumpkins are sensitive to soil salinity and yield will be reduced if levels are too high. Pumpkins can tolerate a soil salinity level of 1.5 deci Siemens per meter $(\mathrm{dS} / \mathrm{m})$ before yield is affected. If soil salinity reaches a level of $3.5 \mathrm{dS} / \mathrm{m}$, a yield loss of 20 to $30 \%$ is expected (Tony N, 2009).

\subsubsection{Sowing}

Pumpkin crops are usually established by direct seeding but they can be sown as transplants. Transplants are usually only considered when trying to establish a very early season crop or when using permanent beds (Tony N, 2009).

2.3.4. Irrigation

To achieve a consistent maximum yield of high quality pumpkins, growers need to irrigate their crops. Furrow irrigation of pumpkins is the preferred option for most inland growers. Furrow irrigation requires an even, gentle slope and a soil type that allows water to spread laterally, without penetrating too deep into the soil. Drip irrigation is used in permanent bed systems and is often used in conjunction with plastic mulch, which helps to minimize weed infestation in fields (Silwana, \& Lucas, 2002). Overhead irrigation is another option in undulating country and can be applied by travelling irrigators, center pivots, lateral moves or fixed sprinkler systems. A pumpkin crop requires about 4 to 8 mega litters per hectare of irrigation water from sowing to harvest (Tony N, 2009).

2.3.5. Fertilizer

The correct amount of fertilizer is important, as too much can result in excessive plant and foliage growth at the expense of fruit yield. Also, female flowers can fail to set if there are excessive levels of nitrogen early in the growing period (Tony N, 2009). 


\subsection{Challenges}

\subsubsection{Diseases}

Foliar diseases are the major problem of pumpkins in humid weather. When conditions are warm and moist early in the season, downy mildew (Pseudoperenospora cubensis) is the most common disease. This shows up as yellow spots on the top surface of leaves. Inspection of the under-surface of the leaf will also reveal the white growth of the fungus. Powdery mildew (Podosphaera axanthi) is a disease in drier conditions that occur later in the season. With this disease, a white, powdery growth occurs on the under-side of leaves first, and then spreads rapidly to cover both sides of the leaves. If not treated with the correct fungicides, both diseases can result in the premature death of foliage and, in extreme cases, death of the plant (Mehl and Epstein, 2007).

2.4.2. Insect pests

Pumpkins are affected by few insect pests. The best known pest, the pumpkin beetle, can cause problems by feeding on leaves of young plants. Once the plant begins to run and grow rapidly, economic damage is rarely significant. The twenty-eight spotted ladybird and its larvae cause similar problems as the pumpkin beetle (Mehl and Epstein, 2007).

\subsection{Pumpkin production in Ethiopia}

Ethiopia is located around the tropical region; the weather makes a suitable environment for the growth of pumpkin. Few years ago, farmers used to produce pumpkin in their gardens together with cereals, in farms near fences for the plants to easily creep on fences and houses, marginal or waste land, on decaying hay and heap of cow dung. There are wide variations in fruit size, weight, shape, color, vine length and branching, leaf size, overall fruit subjective and chemical qualities and seed size among varieties (Meseret E, 2018).

In Ethiopia, pumpkins are widely grown for their fruit utilization that are effectively and efficiently being used for stew preparation to be consumed with Ethiopian traditional spongy thin-layer bread (injira) made from cereal grain called teff. The other most important food product from pumpkin fruit is dried pumpkin which is called 'Duba quanta'. This dried product is used for making delicious stew called 'Duba Wett' and highly used during the period of food scarcity. Pumpkin is a seasonal crop that has been used for human food (Meseret E, 2018).

Recently there are a lot of pumpkin producing areas such as Gambiella Region, Jijiga, Dire- Dawa, Kulubi Harar and other low land area. Most commonly cucurbita pepo Varieties are known and grown in Ethiopia. It is sensitive to frost and ideal temperature of $18^{\circ} \mathrm{C}$ to $30^{\circ} \mathrm{C}$ best for growth. Varieties of C. pepo germinate best with eight hours of sunlight daily and a planting depth of 1.2 centimeters $(0.47 \mathrm{in})$. Seeds planted deeper than 12.5 centimeters (4.9 inch) are not likely to germinate. In a seed batch with 90 percent germination rate, over 90 percent of the plants had sprouted after 29 days from planting. Most pumpkins reach maturity at 3 months to 4 months after sowing. The maturity can be identified by change in fruit colour to orange or pale yellow colour. At this stage, the pumpkin seed attain maturity with higher vigour and viability. The yield depends on many factors which may include soil type, cultivar, irrigation, age of plants and management practices. However, an average yield may range 15 to 25 tonnes/ ha. Pumpkins generally weigh between 3 and 8 kilograms ( 6 and $18 \mathrm{lbs}$.), though the largest cultivars (Meseret E, 2018).

\section{NUTRITIVE VALUE OF PUMPKIN}

\subsection{Component of pumpkin}

The pumpkin is made up of many different parts which give us a perfect fruit once it has matured. It contain several components such as stem, tendril, leaves, lid, pumpkin shell, pulp, ribs, blossom end, cavity, brains, seeds, seed coat nut. Stem is located on the very top of the pumpkin. Brown to brownish green in color and slightly curved; it is attached to the vine and provides nutrients to grow the fruit, just like an umbilical cord. Tendrils are green, thin and hair like structure; while the plant is growing, the tendrils twist around objects on the ground to help anchor the vine and protect it from the elements, like the wind. Leaves of the pumpkin absorb energy from the sun to allow the plant and fruit to grow. When you cut a pumpkin (for carving) around the stem to open it, lid is found. Pumpkin Shells refers to both the skin and the pulp of the fruit. The external layer of the pumpkin is called the skin, or rind. This is a protective layer that keeps insects and disease out of the fruit. Pulp is also known as the meat of the fruit which is used to cook with. Ribs are the external shape of the pumpkin which made up of indented ridges 2running from top to bottom. When the fruit is young a flower blossom is at the end of the fruit.

This is known as the blossom end, which becomes the bottom of the fruit. As the female flowers become pollinated a fruit develops and the flower dies off. Fibrous Strands Better known as brains, this part of the fruit consists of its fibrous strings and seeds. Once the fibrous strings and seeds are removed, you are left with the empty cavity of the fruit. Seeds are located in the center of pumpkin and attached to the fibrous strings. The seeds can be separated, dried and eaten, or used for the next harvest. Seed Coat is the outer layer of the seed which helps to protect the nut inside that will eventually grow into a pumpkin plant. This is also known as the seed jacket. Nut is located inside of the seed. When a seed is planted the moisture and warmth triggers the nut to begin to grow into 
a new plant. Pumpkin fruit is physically composed of seed (Meseret E, 2018).

\subsection{Chemical composition and bioactive components}

The chemical composition of pumpkin varies from one cultivar or species to other. According to Chigwe CB and Saka VW (1994) proximate composition of the pumpkin pulp varied between 75.8 and $91.33 \%$ moisture, 0.2 and $2.7 \%$ crude protein, 0.47 and $2.1 \%$ crude ash and 3.1 and $13 \%$ carbohydrate content. Pumpkin fruits have many nutritional components including polysaccharides, proteins, essential amino acids, valuable antioxidants, carotenoids and minerals. Seeds of pumpkin are rich in oil and the variability in the oil content is due to its broad genetic diversity. Pumpkin seeds have a high nutritional value (table 1), provides good quality oil, and excellent source of protein. Due to the presence of highly unsaturated fatty acids, pumpkin seed oil is well-suited for enhancing nutritional benefits from foods.

Table 1: Bioactive components and their percentage in Pumpkin seed (nutritive value per $100 \mathrm{~g}$ ).

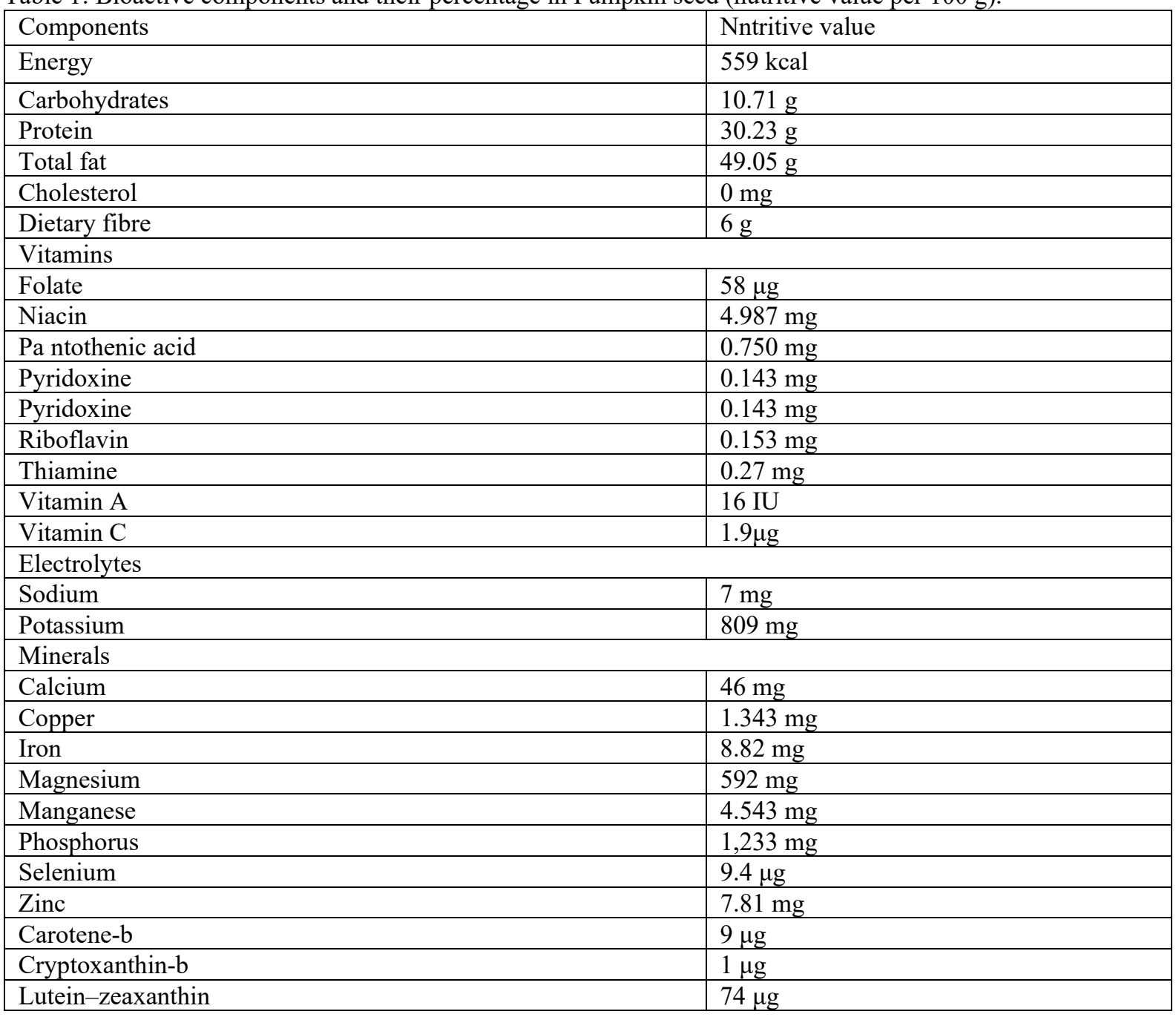

\subsection{Nutritional and dietary uses of Pumpkin}

Pumpkins are consumed as freshly boiled and steamed or in processed form like soup and curry. It is high in $\beta$ carotene, which gives it yellow or orange color. Beta-carotene in plants that have a pleasant yellow-orange color is a major source of vitamin A (Craig W, 1994). It is also high in carbohydrates and minerals. Consumption of carotene containing foods helps in the prevention of dermatological ailments, eye disorders and certain cancers (Dhiman, 209). Incorporation of $\beta$-carotene rich ingredients in the form of pumpkin powder or flour in food products is therefore considered a very effective approach to eradicate vitamin-A related health problems (Dutta et al., 2006)

Nutritional and health protective value of pumpkin draws considerable attention of food scientists in recent years (Mukesh Y, 2010). Food is one of our most basic needs, which provides us energy and also nourishes all our internal organs of the body. Plants produce oil seeds, grains, fruits and vegetables (Murkovic M 2002). Pumpkin has gained a considerable attention in recent years for its nutritional and health promoting values. Pumpkin is cost 
effective and a nutrient rich source; the pumpkin seed flour incorporated complementary food mix is highly nutritive and economical with highly acceptable sensory attributes (Padulosi S. 1998).

\subsection{Therapeutic and Health Promoting Properties}

3.4.1 Anti-carcinogenic effect

Diets high in pumpkin seeds have also been associated with lower risk of gastric, breast, lung and colorectal cancers (Huang X 2004). There are also potential health benefits, including anti-carcinogenic effects, to be gained from the various carotenoid pigments found in pumpkin seed oil (Jian L, 2005). The carotenoids from pumpkin fruits have been linked to the prevention of prostate cancer (Binns C, 2004). There are still various controversies regarding the use of juices of pumpkin fruits in cancer situations; for example, boiled pumpkin juice significantly suppressed the incidence of aberrant cells while fresh pumpkin juice enhanced it. Isolated some basic proteins from pumpkin seeds named MAP2 (MW $2249 \mathrm{Da}$ ) and MAP4 (MW $4650 \mathrm{Da}$ ), and reported inhibition of the growth of leukemia K-562 cells. Moreover, other proteins from pumpkin seeds were reported to inhibit melanoma proliferation. Xia et al. [58]. Isolated a novel ribosome-inactivating protein (RIP) called moschatin from the mature seeds of pumpkin (C. moschata) and a novel immunotoxin moschatin-Ng76 was prepared successfully which efficiently inhibits the growth of targeted melanoma cells M21 with an IC50 (50\% inhibitory concentration) of $0.04 \mathrm{nM}, 1500$ times lower than that of free moschatin (Cheong N, 1997).

3.4.2. Anti-diabetic activity

D-chiro-Inositol was identified in pumpkin (especially in Cucurbita ficifolia) and this compound has been considered as an insulin action mediator (insulin sensitiser) (Quanhong L, 2005). However, the detailed mechanism of antidiabetic action of this component remains to be clarified. Various other components have also been isolated from pumpkin and analyzed for anti-diabetic potential. For example, Kwon et al., (2001) reported that phenolic phytochemicals of pumpkin have anti-diabetic effects in terms of b-glucosidase and a-amylase inhibition. Pumpkin also has hypotensive effects in terms of angiotensin I-converting enzyme-inhibitory activities. Furthermore, Quanhong et al. (Patel P, 2009). also investigated hypoglycaemic substances from pumpkin, and they isolated protein-bound polysaccharide by activity-guided isolation from water-soluble substances of the pumpkin fruits. When this protein-bound polysaccharide from pumpkin fruits (PBPP) was evaluated for hypoglycaemic activity and effects on serum insulin levels in alloxan diabetic rats, and it was found that PBPP can increase the levels of serum insulin, reduce the blood glucose levels and improve tolerance of glucose in alloxaninduced diabetic animals. By considering all these facts, it can be concluded that pumpkin has potential antidiabetic properties, which may suggest the inclusion of this plant in anti-diabetic regimens to treat human diabetes. However, further studies in detail are warranted to explore the mechanistic and therapeutic potential of pumpkins for diabetes.

3.4.3. Antimicrobial and Antifungal effects

Despite the aforementioned health benefits, pumpkin seed oil has been shown to exhibit antimicrobial activity. Pumpkin extracts showed a broad spectrum antimicrobial activity against several bacteria (Rajakaruna N, 2008). Un-irradiated pumpkin seeds were effective against Rhodotorula rubra and Candida albicans at 0.5 and $1.0 \mathrm{mg} / \mathrm{ml}$ concentrations (Reynolds and Martindale. 1996).

3.4.4. Anti-inflammatory effects

Pumpkin-fortified foods are considered as a good source of anti-inflammatory substances, which can help in many diseases such as arthritis (Seo J et al., 2005). Pumpkin seed oil significantly inhibited adjuvant induced arthritis in rats, similar to a well-known anti-inflammatory substance called indomethacin (Srinivasan C, and Cameron AG. 2006). The beta-carotene in pumpkin seeds has anti-inflammatory properties and regular consumption of pumpkin seeds can protect against joint inflammation (Wang H, 2003).

\section{CONCLUSION AND RECOMMENDATIONS}

Among cucurbitaceous vegetables, pumpkin has been appreciated for high yields, long storage life and high nutritive value. Pumpkin is an edible food which can be included in our daily diet that can give various health benefits to improve our overall health. Pumpkin has various effects beneficial to health such as anti-diabetic, anticarcinogenic, antioxidant and anti-microbial potential. There are other various health beneficial effects of pumpkin also reported such as inhibition of kidney stone formation, and hypotensive, anti-inflammatory and bloodcoagulatory effects. There are various food products such as snacks, pies, etc available containing pumpkin alone and in combination with other edible supplements such as ginger and various fruits for human consumption. It would be a good idea to follow up the normal consumption effects in human populations of these products in relation to various chronic diseases such as diabetes, cancer and heart diseases. Pumpkin despite its enormous benefits, information on production, challenges and nutritive value was limited in Ethiopia. This is as a result of inadequate knowledge on its importance and how livelihoods of many families will be affected by its production. Therefore based on the above conclusion pumpkin production in different part of Ethiopia must be studied in detail, various component of pumpkin must be isolated, characterized and evaluated from different parts. 


\section{REFERENCES}

Acosta-Patiño, J., Jime'nez-Balderas, E. and Jua'rez-Oropeza, M. (2001). Hypoglycemic action of Cucurbita ficifolia on type 2 diabetic patients with moderately high blood glucose levels. J Ethnopharmacol; 77:99-101.

Bello, M., Farade, O., Adewusi, A. and Olawore, N. (2008). Studies on some lesser known Nigerian fruits. African Journal of Biotechnology. 7(1), 3972 -3979.

Bendich A. (1989). Carotenoids and the immune response. J Nutr; 119:112-115.

Berteram JS, Bortkiewicz H. (1995). Dietary carotenoid inhibit neoplastic transformation and modulate gene expression in mouse and human cell. Am. J. Clin. Nutr.; 62:132-136.

Binns, W., Jian, L. and Lee, A. (2004). The relationship between dietary carotenoids and prostate cancer risk in southeast Chinese men. Asia Pac J Clin Nutr. 13:S117.

Caili, F., Huan, Shi. and Ouanlong, L. (2006). A review on pharmacological activities and utilization technologies of pumpkin. Pl Food Hum Nutr 61:73-80.

Cheong, N., Choi, Y. and Kim, W. (1997). Purification and characterization of an antifungal PR-5 protein from pumpkin leaves. Mol Cell; 7:214-219.

Chigwe, C. and Saka, V. (1994): Collection and Characterization of Malawi Pumpkin Germplasm. Zim. J. Agric. Res. 32(2):139-149.

Craig, W. (1994). Phytochemicals: guardians of our health. J Am Diet Assoc. 1994; 977:1-11.

Dhiman, (209). African Cucurbita pepo, Properties of seed and variability in fatty acid composition of seed oil. J. of Phytochemistry. 54(1):71-75.

Dutta, D., Dutta, A., Raychaudhuri, U. and Chakraborty, R. (2006). Rheological characteristics and thermal degradation kinetics of beta-carotene in pumpkin puree. J. Food Eng; 76:538-546.

Gohari Ardabili, A., Farhoosh, R., \& Haddad Khodaparast, M. H. (2011). Chemical composition and physicochemical properties of pumpkin seeds (Cucurbita pepo subsp. pepo Var. styriaka) grown in Iran. Journal of Agricultural Science and Technology, 13(SUPPL.), 1053-1063.

Huang, X., Hirose, K. and Wakai, K. (2004). Comparison of lifestyle risk factors by family history for gastric, breast, lung and colorectal cancer. Asian Pac J Cancer Prev. 2004; 5:419-427.

Jian, L, D. and Lee, H. (2005). Do dietary lycopene and other carotenoids protect against prostate cancer? Int J Cancer; 113:1010-1014.

Lee, Y., Chung, W. and Ezura, H. (2003). Efficient plant regeneration via organogenesis in winter squash (Cucurbita maxima). Plant Sci 164:413-418.

Megersa , M., Asfaw, Z., Kelbessa, E., Beyene, A., \& Woldeab, B. (2013). An ethnobotanical study of medicinal plants in Wayu Tuka District, East Welega Zone of Oromia Regional State, West Ethiopia. Journal of Ethnobiology and Ethnomedicine. 9(68), 1-18.

Mehl, H. L., and L. Epstein (2007). "Identification of Fusarium solani f. sp. cucurbitae race 1 and race 2 with PCR and production of disease-free pumpkin seeds." Plant Disease 91.10 (2007): 1288-1292.

Meseret, E. (2018). Extraction and Characterization of Essential Oil From Pumpkin Seed. Diss. AAU, 2018.

Mukesh, Y., Shalini, J., Radha, T., Prasad, G. and Hariom, Y. (2010). Medicinal and biological potential of pumpkin: an updated review. Nutrition Research Reviews; 23:184-190.

Murkovic, M., Hillebrand, A. and Winkler, J. (1996). Variability of fatty acid content in pumpkin seeds (Cucurbita pepo L.), Z lebensm unters forsch, 203(3), 216-219.

Murkovic, M., Mulleder, U. and Neunteu, H. (2002). Carotenoid content in different varieties of pumpkins. J. Food Compos. Anal. 15:633-638.

Nath, P., Dutta, O. P., Velayudhan, S. and Swamy, K. (1979). Inheritance of Leaf Characters in Pumpkin (Cucurbita Maxima Duch). Indian Journal of Horticulture, 36(2), 171-174.

Okoli, B. and Nyanayo, B. (1988). Poynology of Telfairia L. (Cucurbitacae), Folia geobotanica et phytotaxonomica, 2, 281-286.

Padulosi, S. (1998). Priority setting for Underutilized and neglected plant species of Mediterranean region. Report of the IPGRI conference. Aleppo, Syria: ICARDA, 1998.

Patel, P. (2009). Study of certain physiological and histo-architectural changes associated with growth and ripening of some underutilized fruits. Journal of Ethno pharmacology, 64:271-276.

Quanhong, L., Caili, F. and Yukui, R. (2005). Effects of protein-bound polysaccharide isolated from pumpkin on insulin in diabetic rats. Plant Food Hum Nutr. 2005; 60:13-16.

Rajakaruna, N., Harris, C. and Towers, G. (2008). Antimicrobial Activity of Plants Collected from Serpentine Outcrops in Sri Lanka. Pharmaceutical Biology; 40(3):235-244.

Reynolds, J. and Martindale, T. (1996). The Extra Pharmacopoeia, thirty first ed. Royal Pharmaceutical Society of Great Britain, London, 1996.

Seo, J., Burri, B.J, Quan, Z. and Neidlinger, T. (2005). Extraction and chromatography of carotenoids from pumpkin. J. Chromatography A; 1073:371-375.

Silwana, T. and Lucas, E. (2002). The effect of planting combinations and weeding on the growth and yield of 
component crops of maize/bean and maize/pumpkin intercrops. The Journal of Agricultural Science, 138(2), 193-200.

Srinivasan, C. and Cameron, A. (2006). Nutrients and their functions, Technologies of Pumpkin. Plant Foods for Human Nutrition; 61:73-80.

Suphakarn, S., Yarnnon, C. and Ngunboonsri, P. (1987). The effect of pumpkin seeds on oxalcrystalluria and urinary compositions of children in hyper endemic area, American journal clinical nutrition, 45, 115-21.

Swiader, J., Chyan, Y. and Freiji, F. (1994). Genotypic differences in nitrate uptake and utilization efficiency in pumpkin hybrids. Journal of Plant Nutrition, 17(10), 1687-1699.

Tony, N. (2009). Pumpkin production. District Horticulturist Vegetables, Riverina, Yanco

Wang, H. (2003). Isolation of cucurmoschin, a novel antifungal peptide abundant in arginine, glutamate and glycineresidues from black pumpkin seeds. Peptides; 24:969-972. 